\title{
EFFECT OF ORGANIC FERTILIZER, GYPSUM AND FOLIAR-CA ON YIELD, YIELD COMPONENTS AND QUALITY OF PEANUT PLANT GROWN IN SANDY SOIL
}

\author{
Faten A. Al-Kamar, Y. M. El-Edfawy and R. M. Derar \\ Soils, Water and Environment Research Institute, Agric. Res. Center, Giza, Egypt.
}

Received: May. 9, 2018

Accepted: Jun. 26, 2018

\begin{abstract}
Two field experiment were conducted at Ismailia Experiment Research Station, Ismailia Governorate, Egypt during the two successive seasons of 2015 and 2016 to evaluate the effect of different rates of compost application $\left(0,12.5\right.$ and $\left.25 \mathrm{Mg} \mathrm{ha}^{-1}\right)$, gypsum at rates of $\left(0,0.6\right.$ and $\left.1.2 \mathrm{Mg} \mathrm{ha}^{-1}\right)$ and Ca-foliar $\left(300 \mathrm{mg} \mathrm{L}^{-1}\right)$ and its combination application on yield and quality of peanut grown in a sandy soil. Application of compost significantly increased pods and grain yield, shelling percentage and 100 grain weight of peanut as compared to control. The increases were 29.6 and $35.4 \%$ for pod and 35.5 and $41.40 \%$ for grain due applications of 12.5 and $25 \mathrm{Mg} \mathrm{ha}^{-1}$ compost. Application any of the two gypsum rates increased pods, grain yield, shelling percentage and 100 seed weight with non-significant difference between two rates. Addition any of the two rates of compost significantly increased $\mathrm{N}, \mathrm{K}, \mathrm{Fe}, \mathrm{Zn}$ and Mn contents of straw and seed. Two rates of gypsum also increased the same nutrient with non-significant difference between two rates. Oil and protein contents of grain significantly increased due to application of compost and /or gypsum.
\end{abstract}

Key words: Peanut, Sandy soil, compost. Gypsum.

\section{INTRODUCTION}

Peanut is considered one of the most important oil seeds grown in sandy soil, due to its rich seed in protein and oil. Also it is an important economical crop to agricultural producer on commercial scale. There are many aspects that must be managed properly to ensure optimum production, one of major important soil fertility. Sandy soil generally having poor hydro-physical and nutritional properties such as low water holding capacity, low cation exchange, low contains available nutrients and as well as poor structure and low level of organic matter (Chesworth 2008). These sandy soils require special management to facilitate their suitability for agriculture. An example for such management efforts is application of composted material. Over the year soil properties and crop yield have been improved by addition of different types of compost to agricultural soil (Staffella and Great 2000; Mobark et al. 2000). Addition organic manure to sandy soil improve soil fertility and hence its contents of NPK and micronutrients which is consequently reflected in plant growth and yield (Ismail 2002; Khater et al. 2004 and Hussein et al. 2011). Organic manure also improves the water holding capacity of sandy soil, improve soil structure and soil aeration (Abou El-Maged et al. 2006, Bayu et al. 2006 and Agegnehu et al. 2015).

Calcium is indispensable nutrient for peanut seed and pods development. Peanut leaking Ca may form undeveloped pods called "POP" or have poor germination and vigor. These occurrences can greatly reduce yield and grad factors of peanut. Pods must have obtained $\mathrm{Ca}$ from surrounding soil because $\mathrm{Ca}$ is generally immobile in the phloem (Keisling and Walker 1982). Thus adequate $\mathrm{Ca}$ in pegging zone is essential 
Faten A. Al-Kamar, et al.,

for proper peanut development (Summer et al. 1988). Addition of gypsum as Ca fertilizer therefore is common practice to increase $\mathrm{Ca}$ in pegging zone and improve peanut yield and grade (Hallock amd Allison 1980 a). Calcium also affect the water status and membrane permeability of peanut leaves under moisture stress condition. The extent of membrane and loss of water is less severing in leaves of $\mathrm{Ca}$ compared to no receiving a $\mathrm{Ca}$ supplement (Chari et al. 1986).

The aim of this study to evaluate the effect of different rates of compost, gypsum and Ca-foliar on peanut yield and its quality grown in sandy soil.

\section{MATERIALS AND METHODS}

Two field experiment were conducted during two the successive seasons of 2015 and 2016 at Ismailia Research Station, Ismailia governorate, to study the effect of different rates of compost, gypsum and Ca-foliar application and its combinations on peanut yield and its quality. The experimental treatments were arranged in a complete randomized block design. The experiment included 12 treatments with three replicates as follow:
(1) Control (without application).

(2) Compost application at rate of $12.5 \mathrm{Mg}$ $\mathrm{ha}^{-1}\left(\mathrm{C}_{1}\right)$.

(3) Compost application at rate of $25 \mathrm{Mg}$ ha $^{-1}\left(C_{2}\right)$.

(4) Gypsum application at rate of $0.6 \mathrm{Mg}$ $\mathrm{ha}^{-1}\left(\mathrm{G}_{1}\right)$.

(5) Gypsum application at rate of $1.2 \mathrm{Mg}$ $\mathrm{ha}^{-1}\left(\mathrm{G}_{1}\right)$.

(6) Ca-chelate at rate of $300 \mathrm{mg} \mathrm{L}^{-1}$ as foliar application ( $\mathrm{Ca}_{\text {foliar }}$ )

(7) $\mathrm{C}_{1}+\mathrm{G}_{1}$

(8) $C_{1}+G_{2}$

(9) $C_{2}+G_{1}$

(10) $C_{2}+G_{2}$

(11) $\mathrm{C}_{1}+\mathrm{Ca}_{\text {foliar }}$

(12) $\mathrm{C}_{2}+\mathrm{Ca}_{\text {foliar }}$

The levels of compost were added at two weeks before sowing, gypsum was applied in furrow at sowing on both sides of crop row. Foliar Ca-chelate was sprayed at 30, 45 and 60 days after sowing. Physical and chemical characteristics of the studied soil and applied compost were presented in Tables 1 and 2 which analyzed according to Klute (1986). After harvesting soil samples were collected from each plot air dried and analyzed for $\mathrm{N}, \mathrm{P}$ and $\mathrm{K}$.

Table 1. Physical and chemical properties of the studied soil.

\begin{tabular}{|c|c|c|c|c|c|c|c|c|c|c|}
\hline \multicolumn{4}{|c|}{ Particle size distribution (\%) } & \multirow{2}{*}{$\begin{array}{l}\text { Texture } \\
\text { class }\end{array}$} & \multirow{2}{*}{$\begin{array}{c}\text { Field } \\
\text { capacity }\end{array}$} & \multirow{2}{*}{$\begin{array}{c}\text { CEC } \\
\text { (cmolc } \\
\text { kg }^{-1} \\
\text { soil) }\end{array}$} & \multirow{2}{*}{$\begin{array}{c}\mathrm{CaCO} 3 \\
(\%)\end{array}$} & \multirow[b]{2}{*}{${ }^{*} \mathrm{pH}$} & \multirow{2}{*}{$\begin{array}{l}\text { O.M } \\
(\%)\end{array}$} & \multirow{2}{*}{$\begin{array}{c}E C \\
\left.(\mathrm{dSm})^{-1}\right)\end{array}$} \\
\hline $\begin{array}{l}\text { Coarse } \\
\text { sand }\end{array}$ & $\begin{array}{l}\text { Fine } \\
\text { sand }\end{array}$ & Silt & Clay & & & & & & & \\
\hline 67.6 & 28.1 & 2.2 & 2.1 & Sandy & 12.1 & 5.6 & 1.7 & 7.32 & 0.45 & 0.44 \\
\hline \multicolumn{4}{|c|}{${ }^{*}$ Soluble cations (mmolc L ${ }^{-1}$ ) } & \multicolumn{4}{|c|}{${ }^{*}$ Soluble anions (mmolc $\mathrm{L}^{-1}$ ) } & \multicolumn{3}{|c|}{$\begin{array}{l}\text { Available nutrient } \\
\text { (mg kg }{ }^{-1} \text { soil) }\end{array}$} \\
\hline $\mathrm{Ca}^{++}$ & $\mathbf{M g}^{++}$ & $\mathrm{Na}^{+}$ & $\mathrm{K}^{+}$ & $\mathrm{CO}^{-}$ & $\mathrm{HCO}^{-}$ & $\mathrm{Cl}^{-}$ & SO4"- & $\mathbf{N}$ & $\mathbf{P}$ & K \\
\hline 1.2 & 1.7 & 1.25 & 0.2 & 0 & 2.1 & 1.61 & 0.64 & 19.5 & 9.1 & 38.5 \\
\hline
\end{tabular}

${ }^{*} \mathrm{pH}$ of $1: 2.5$ soil : water suspension. EC: of soil past extract

Table 2. Physical and chemical analysis of the applied compost

\begin{tabular}{|c|c|c|c|c|c|c|c|c|}
\hline Density & $\begin{array}{c}\text { O.M } \\
(\%)\end{array}$ & $\begin{array}{c}\text { Organic } \\
\text { C }\end{array}$ & $\begin{array}{c}\text { Total N } \\
(\%)\end{array}$ & $\begin{array}{c}\text { Total P } \\
(\%)\end{array}$ & $\begin{array}{c}\text { Total K } \\
(\%)\end{array}$ & C/N ratio & $\begin{array}{c}\text { EC } \\
(\mathrm{dSm}-1)\end{array}$ & pH \\
\hline 0.62 & 38.8 & 22.5 & 1.2 & 0.27 & 0.32 & 18.75 & 2.6 & 7.48 \\
\hline
\end{tabular}


Seed of peanut (C.V. Giza) were sown at 15 may. All treatments were fertilized with $250 \mathrm{~kg} \mathrm{ha}^{-1} \mathrm{P}_{2} \mathrm{O}_{5}$ as calcium super phosphate during soil preparation, Nitrogen fertilizer was applied at rate of $70 \mathrm{~kg} \mathrm{ha}^{-1}$ as ammonium nitrate. Potassium was applied at a rate of $200 \mathrm{~kg}$ $\mathrm{ha}^{-1}$ as potassium sulfate.

Peanut plants were harvested after 140 days from sowing. The yield for each grain and straw were calculated. pod yield at first mature pods were harvested from each plot. Then they located outside for a week then were weighted. $250 \mathrm{gm}$ of dried mature pods was selected as a sample. The shell and seeds were separated and weighted. The ratio of these weighted grain and pods define as shelling percentage. Peanut grain yield was also calculated as pods yield multiply shelling percentage. Plant samples were oven dried at $70 \mathrm{C}^{\circ}$, grounded and wet digested using mixture of $\mathrm{H}_{2} \mathrm{SO}_{4}$ and $\mathrm{HClO}_{4}$ according Page et al. (1982). Contents of macro and micro nutrients were determined in grain and straw yield according to Black (1982). Oil content of grain was determined by using a soxchlet apparatus according A.O.A.C. (1990). Crude protein was calculated by multiplied total $\mathrm{N}$ content by 6.25 . bulk density was determined according to Singh (1980). Organic C was determined using Walkley and Black method (Jackson 1973). Total N, P and K were determined as mentioned regarding plant analysis. The obtained results were statistically analyzed according to Sedecor and Cochron (1980), to define the values of L.S.D.

\section{RESULTS AND DISCUSSION}

Data in Table 3. Show the effect of compost, gypsum, $\mathrm{Ca}$ foliar and their combination on peanut pods and grain yield. Compost addition significantly increased pods and grain yield relative to the control. The increases were 29.6 and
$35.4 \%$ for pods and 35.5 and $\mathbf{4 1 . 4 2} \%$ for grain to application of 12 and $25 \mathrm{Mg} \mathrm{ha}^{-1}$ compost, respectively without significant difference between both two rates. The beneficial effect of compost on pods and grain yield of peanut may be due to these applied organic materials augmented soil organic matter content that led to improve soil physio-chemical, biological and hydrological characteristics and their its fertility status. Khater et al. (2004), Ewees et al. (2008) and Ewees and Abd El-Hafez (2010) stated that the highest dry matter accumulation, grain yield and oil percentage in seed yield were achieved by addition of 0.6 ton/fed farmyard manure. Radwan and Awad (2002) found that compost addition increased pods and grain yield of peanut. Salama and Rovira. (1994) found that highest number of flower/plant and pods yield of peanut was obtained by using of $20 \mathrm{~m}^{3} / \mathrm{fed}$ organic manure. These data confirm with obtained by Radwan and Awad (2002) and Aza and Abdel Wahab (2013).

The different gypsum application significantly increased pods and grain yield and weight of 100 seed compared to control (Table 3). The relative increases were 21.2 and $23.8 \%$ for pods and 30.8 and $35.5 \%$ for grain due to application of 0.6 and $1.2 \mathrm{Mg} \mathrm{ha}^{-1}$ gypsum, respectively with non-significant difference between the two application rates. These data confirmed with those obtained by Aza and Abdel-Wahab (2013); Arnold (2014) and Yang (2015). Safarzadeh et al. (2002) and Safarzadeh (2004) stated that calcium is most critical element in growth and development of peanut seeds. Enough calcium content in the soil around the peanut pods leads to increase yield, oil and protein content of the grain. It decreases decayed pod and increase absorption of other nutritional elements from the soil. On the other hand, low content of calcium around the peg zone 
Faten A. Al-Kamar, et al.,

of peanut leads to several serious problems for peanut including the production of immature pod, black embryo seed, weak germination of seed and increase production of aflatoxin (Grichar et al. 2002).

Ca-foliar sprayed showed no significant effects on pods and grain of peanut. As stated by Safarzadeh et al. (2002) it may be due to calcium is absorbed through leave and root of peanut and then transmitted to the aerial part of plant but is not transmitted from the aerial parts of the plant to the pods, so the calcium must be adequate around the growing pods. Summer et al. (1988) pointed out that peanut pods cannot be received calcium from the plant, it must be delivered to the pods directly from the soil.
Combined applications of $\mathrm{C}_{1}$ or $\mathrm{C}_{2}$ with any of $G_{1}$ or $G_{2}$ or Ca-foliar achieved the highest yields for both of pods and grain comparing with any of the solo experimental treatments. For example, the highest pods yield of $4.5 \mathrm{Mg} \mathrm{ha}^{-1}$ recorded due to application of $\mathrm{C}_{2}+\mathrm{G}_{2}$ compared to solo application of compost or gypsum The relative increase over the control were 27.8 and $39.8 \%$, respectively. The corresponding relatively increases of the highest grain yield of $3.15 \mathrm{Mg} \mathrm{ha}^{-1}$ were noticed under $\left(C_{2}+G_{2}\right)$ and recorded 31.8 and $37.6 \%$ relative to $C_{2}$ and $G_{2}$, respectively. The significant effect of combined application of compost and gypsum may be due to that compost led to improve chemical and physical properties of sandy soil, while gypsum increase calcium in the pegging zone where pods take $\mathrm{Ca}$ for development (Walker 1978).

Table 3. Effect of compost, gypsum and foliar-Ca application on peanut yield and yield component (combined over the two seasons).

\begin{tabular}{|c|c|c|c|c|c|c|}
\hline Treatments & $\begin{array}{c}\text { Pods yield } \\
\left(\mathrm{Mg} \mathrm{ha}^{-1}\right)\end{array}$ & $\begin{array}{c}\text { Grain yield } \\
\left(\mathrm{Mg} \mathrm{ha}^{-1}\right)\end{array}$ & $\begin{array}{l}\text { Shelling } \\
\text { yield } \\
\left(\mathrm{Mg} \mathrm{ha}^{-1}\right)\end{array}$ & $\begin{array}{c}100 \text { grain } \\
\text { weight } \\
\text { (g) }\end{array}$ & $\begin{array}{c}\text { Protein } \\
(\%)\end{array}$ & $\begin{array}{l}\text { Oil } \\
\text { (\%) }\end{array}$ \\
\hline Control & 2.60 & 1.69 & 65 & 88.2 & 21.2 & 43.2 \\
\hline $\mathrm{C}_{1}$ & 3.37 & 2.29 & 68 & 92.5 & 24.5 & 46.5 \\
\hline $\mathrm{C}_{2}$ & 3.52 & 2.39 & 68 & 93.1 & 24.7 & 47.1 \\
\hline $\mathrm{G}_{1}$ & 3.15 & 2.21 & 70 & 92.5 & 23.6 & 45.3 \\
\hline G2 & 3.22 & 2.29 & 71 & 92.6 & 23.8 & 46.6 \\
\hline $\mathrm{Ca}_{\text {foliar }}$ & 2.76 & 1.78 & 66 & 89.3 & 22.0 & 43.9 \\
\hline$C_{1}+G_{1}$ & 4.10 & 3.03 & 74 & 95.5 & 25.6 & 48.2 \\
\hline $\mathrm{C} 1+\mathrm{G} 2$ & 4.20 & 3.15 & 75 & 95.4 & 25.9 & 48.5 \\
\hline$C_{2}+G_{1}$ & 4.30 & 3.09 & 75 & 95.7 & 26.8 & 49.1 \\
\hline $\mathrm{C}_{2}+\mathrm{G}_{2}$ & 4.50 & 3.15 & 76 & 95.7 & 26.9 & 47.8 \\
\hline $\mathrm{C}_{1}+\mathrm{Ca}_{\text {foliar }}$ & 3.42 & 2.36 & 69 & 93.5 & 25.1 & 47.3 \\
\hline $\mathrm{C}_{2}+\mathrm{Ca}_{\text {foliar }}$ & 3.69 & 2.4 & 69 & 94.1 & 25.3 & 47.8 \\
\hline$\angle S D O_{.05}$ & 0.22 & 0.18 & 2.3 & 2.2 & 1.1 & 2.2 \\
\hline
\end{tabular}

$\mathrm{C}_{1}$ : compost at rate of $12.5 \mathrm{Mg} \mathrm{ha}^{-1}$ compost, $\mathrm{C}_{2}$ : compost at rate of $25 \mathrm{Mg} \mathrm{ha}^{-1}$ compost, $\mathrm{G}_{1}$ : gypsum at rate of $0.6 \mathrm{Mg} \mathrm{ha}^{-1}, \mathrm{G}_{2}$ : gypsum at rate of $1.2 \mathrm{Mg} \mathrm{ha}^{-1}$, Ca foliar: Ca-chelate at rate of $300 \mathrm{mg} \mathrm{L}^{-1}$ as foliar application, ns: non-significant at the $5 \%$ levels of probability at L.S.D test. 


\section{Protein and oil content of grain}

Data in Table 3 show that protein and oil grain content significantly improved by different application of compost and / or gypsum and their combination compared to control. It worth to mention that generally, the highest values of protein and oil content in grain were obtained with treatment of $\mathrm{C}_{2}+\mathrm{G}_{2}$. However, there were non-significant difference between $C_{2}+G 2$ and $C_{2}+$ $\mathrm{G}_{1}$ treatment.

\section{Nutrient contents}

As shown in Tables 4 and 5 application of compost significantly increased grain and straw NPK concentration. Similar trends were noticed by Radwan and Awad (2002); Rao and Shaktawat (2005); and Aza and Abd El-Wahab (2013) who reported that application of organic manure increased $\mathrm{N}, \mathrm{P}$ and $\mathrm{K}$ contents in various parts of peanut and their uptake. They concluded that organic manure improves moisture retention of sandy soil and nutrient use efficiency and consequently increase the amount of NPK absorbed by plant. Reducing the leaching out of nutrient and ability of active groups of organic matter (fulvic and humic acid) to retain inorganic elements in complete and chelate form which broken down slowly by microorganisms and release elements over period (Rao and Shaktawat 2005).

Table 4. Effect of compost, gypsum and foliar-Ca application on macro and micro nutrients, protein and oil contents in grain of peanut plant (combined over the two seasons).

\begin{tabular}{|c|c|c|c|c|c|c|}
\hline Treatments & $\begin{array}{c}\mathrm{N} \\
(\%)\end{array}$ & $\begin{array}{c}\mathrm{P} \\
(\%)\end{array}$ & $\begin{array}{c}\mathrm{K} \\
(\%)\end{array}$ & $\begin{array}{c}\mathrm{Zn} \\
(\mathrm{ppm})\end{array}$ & $\begin{array}{c}\mathrm{Fe} \\
(\mathrm{ppm})\end{array}$ & $\begin{array}{c}\mathrm{Mn} \\
(\mathrm{ppm})\end{array}$ \\
\hline Control & 3.31 & 0.33 & 0.52 & 30.2 & 81.2 & 11.2 \\
\hline $\mathrm{C}_{1}$ & 3.80 & 0.42 & 0.70 & 37.1 & 88.4 & 12.6 \\
\hline $\mathrm{C}_{2}$ & 3.91 & 0.44 & 0.76 & 38.2 & 90.1 & 12.7 \\
\hline $\mathrm{G}_{1}$ & 3.94 & 0.35 & 0.63 & 35.7 & 85.8 & 11.4 \\
\hline $\mathrm{G}_{2}$ & 3.95 & 0.32 & 0.65 & 35.6 & 85.7 & 11.6 \\
\hline $\mathrm{Ca}_{\text {foliar }}$ & 3.70 & 0.35 & 0.60 & 31.5 & 85.4 & 11.5 \\
\hline $\mathrm{C}_{1}+\mathrm{G}_{1}$ & 4.12 & 0.45 & 0.71 & 37.5 & 89.4 & 12.8 \\
\hline $\mathrm{C}_{1}+\mathrm{G}_{2}$ & 4.16 & 0.46 & 0.72 & 37.6 & 89.9 & 12.7 \\
\hline $\mathrm{C}_{2}+\mathrm{G}_{1}$ & 4.40 & 0.47 & 0.85 & 38.9 & 89.8 & 12.9 \\
\hline $\mathrm{C}_{2}+\mathrm{G}_{2}$ & 4.34 & 0.46 & 0.82 & 39.1 & 88.8 & 12.9 \\
\hline $\mathrm{C}_{1}+\mathrm{Ca}_{\text {foliar }}$ & 3.95 & 0.43 & 0.66 & 38.3 & 89.8 & 12.7 \\
\hline $\mathrm{C}_{2}+\mathrm{Ca}_{\text {foliar }}$ & 4.35 & 0.47 & 0.72 & 39.1 & 89.9 & 12.8 \\
\hline$L S D 0_{.05}$ & 0.32 & 0.05 & 0.10 & 1.9 & 4.1 & 0.95 \\
\hline
\end{tabular}


Faten A. Al-Kamar, et al.,

$\mathrm{C}_{1}$ : compost at rate of12.5 $\mathrm{Mg} \mathrm{ha}^{-1}$ compost, $\mathrm{C}_{2}$ : compost at rate of $25 \mathrm{Mg} \mathrm{ha}^{-1}$ compost, $\mathrm{G}_{1}$ : gypsum at rate of $0.6 \mathrm{Mg} \mathrm{ha}^{-1}, \mathrm{G}_{2}$ : gypsum at rate of $1.2 \mathrm{Mg} \mathrm{ha}^{-1}, \mathrm{Ca}_{\text {foliar }}$ : Ca-chelate at rate of $300 \mathrm{mg} \mathrm{L}^{-1}$ as foliar application, $\mathrm{ns:}$ non-significant at the $5 \%$ levels of probability at L.S.D test.

Table 5. Effect of compost, gypsum and foliar-Ca application on N, P, K, Zn, Fe, and Mn in straw of peanut (combined over the two seasons).

\begin{tabular}{|c|c|c|c|c|c|c|}
\hline Treatments & $\begin{array}{c}\mathrm{N} \\
(\%)\end{array}$ & $\begin{array}{c}\mathrm{P} \\
(\%)\end{array}$ & $\begin{array}{c}\mathrm{K} \\
(\%)\end{array}$ & $\begin{array}{c}\mathrm{Zn} \\
(\mathrm{ppm})\end{array}$ & $\begin{array}{c}\mathrm{Fe} \\
(\mathrm{ppm})\end{array}$ & $\begin{array}{c}\mathrm{Mn} \\
(\mathrm{ppm})\end{array}$ \\
\hline Control & 1.40 & 0.27 & 1.41 & 23 & 105 & 9 \\
\hline $\mathrm{C}_{1}$ & 1.55 & 0.28 & 1.7 & 28 & 120 & 15 \\
\hline $\mathrm{C}_{2}$ & 1.63 & 0.3 & 1.85 & 29 & 122 & 16 \\
\hline $\mathrm{G}_{1}$ & 1.51 & 0.27 & 1.54 & 26 & 116 & 10 \\
\hline $\mathrm{G}_{2}$ & 1.52 & 0.27 & 1.55 & 26 & 112 & 11 \\
\hline $\mathrm{Ca}_{\text {foliar }}$ & 1.46 & 0.27 & 1.56 & 24 & 107 & 10 \\
\hline $\mathrm{C}_{1}+\mathrm{G}_{1}$ & 1.68 & 0.28 & 1.82 & 29 & 122 & 16 \\
\hline $\mathrm{C}_{1}+\mathrm{G}_{2}$ & 1.69 & 0.28 & 1.85 & 29 & 123 & 17 \\
\hline $\mathrm{C}_{2}+\mathrm{G}_{1}$ & 1.69 & 0.29 & 1.85 & 31 & 131 & 18 \\
\hline $\mathrm{C}_{2}+\mathrm{G}_{2}$ & 1.72 & 0.3 & 1.90 & 32 & 133 & 18 \\
\hline $\mathrm{C}_{1}+\mathrm{Ca}_{\text {foliar }}$ & 1.67 & 0.27 & 1.82 & 26 & 123 & 15 \\
\hline $\mathrm{C}_{2}+\mathrm{Ca}_{\text {foliar }}$ & 1.70 & 0.27 & 1.83 & 32 & 130 & 17 \\
\hline$L S D 0_{.05}$ & 0.10 & $n . s$ & 0.14 & 2.3 & 4.2 & 1.3 \\
\hline
\end{tabular}

$\mathrm{C}_{1}$ : compost at rate of $12.5 \mathrm{Mg} \mathrm{ha}^{-1}$ compost, $\mathrm{C}_{2}$ : compost at rate of $25 \mathrm{Mg} \mathrm{ha}^{-1}$ compost, $\mathrm{G}_{1}$ : gypsum at rate of $0.6 \mathrm{Mg} \mathrm{ha}^{-1}, \mathrm{G}_{2}$ : gypsum at rate of $1.2 \mathrm{Mg} \mathrm{ha}^{-1}, \mathrm{Ca}_{\text {foliar: }}$ : Ca-chelate at rate of $300 \mathrm{mg} \mathrm{L}^{-1}$ as foliar application, ns: non-significant at the $5 \%$ levels of probability at L.S.D test.

In general, the combination treatments significantly increased NPK concentration on peanut straw and grain compared to control or solo treatments, without significant difference between two rates of gypsum or compost. On the other hand, the positive influence of gypsum application owing to be results of improved nutritional environment in the rhizosphere, as well as in the plant system which to translocation of NPK to reproduction parts which ultimate increased the concentration of these nutrient (Safarzadeh, 2004; Rao and Shaktawat 2005 and Alcorado and Rechcigl 1993). The combined between compost and gypsum were significant towards the NPK concentration of these nutrient in straw and grain. The positive effect of addition gypsum and compost on nutrient contents of plant may be due to biological oxidized of gypsum in presence of organic matter in soil produce $\mathrm{H}_{2} \mathrm{SO}_{4}$ which lowers the soil $\mathrm{pH}$ and improving physical and chemical properties of sandy soil which effect on both water and nutrients availability (EIBanna et al. 2004; Aza and Abdelwahab 2013 and Mahrous et al. 2015).

With respect to micronutrients of straw and grain they mannered trends similar to the pervious discussed trends for NPK.

\section{REFERENCES}


A.O.A.C. (1990). Official methods of analysis of the association of official analytical chemists. 12ed. Washington.

Abou El-Maged, M. A., M. El-Bassiony and Z. F. Fawzy (2006). Effect of organic manure with or without chemical fertilizers on growth, yield and quality of some varieties of broccoli plant. J. Appl. Sci. Res. 2: 791-798.

Agegnehu, A., M. Adrian, N. Paul, B. Nelson, M. Greamwvright and B. Micheal (2015). Biochar and biochar compost as soil amendments: Effects on peanut yield, soil properties and greenhouse gas emissions in tropical North Queensland, Australia. Agric. Ecosystem and Environ. 2-12.

Alcorado, I. S. and J. E. Recheigl (1993). Phosphogypsum in agriculture: A review Advances in Agronomy 49: 55118.

Arnold, J. A. (2014). Effect of soil calcium and gypsum rates on yield, grad and seed quality of two runner-types peanut. Ms. Theses, Alabama, Gorgea.

Aza, A. and M. M. Abdelwahab (2013). Effect of different sources of calcium, organic and inorganic nitrogen on sandy soil, peanut yield and components. 26 Sept, Top class J. of Agric. Res. 1(5): 51 - 59.

Bayu, W., N. F. G. Rothman, P. S. Hammers and G. Alemu (2006). Effect of farmyard manure and inorganic fertilizers on sorghum growth, yield and nitrogen use in a semiarid area of Ethiopia. J. Plant Nutrition 29: 391 407.

Black, C. A. (1982). Methods of analysis, Part 2. American Society of Agronomy Inc. Publisher. Madison, Wisconsin U.S.A.

Chari, M. K., T. G. Gupta, K. Prasad, S. K. Sastry and M. U. Kumar (1986). Enhancement of water stress by calcium pretreatment in groundnut and cowpea plants subjected to moisture stress. Plant Soil 91: 104 114.

Chesworth, W. (2008). Encyclopedia of soil science. Springes Dordmechi, Netherland. 614 PP.

El-Banna, T. A., T. A. Abu-Defan, M. M. I. Selem and T. A. El-Maghraby (2004). Potassium fertilization and soil amendment interaction and their effect on wheat irrigated with different water qualities. J. Agric. Sci. Mansoura Uni. 29: 5953 - 5963.

Ewees, M. S. A. and A. A. Abdel Hafez (2010). Response of maize grain yield by applying organic manure, bioinoculation and element sulphour as an alternative strategy to avoid the possible chemical pollution. Egypt J. Soil Sci. 50(1): 27-50.

Ewees, M. S., A. S. H. Osama and D. M. EI Sewff (2008). Significant of applied organic manure combined with $\mathrm{N}$ mineral fertilizer to alleviate the possible risks of chemical pollution for broccoli. Egypt J. Soil. Sci. 48 (3): $343-366$.

Grichar, W. J., B. A. Basler and K. D. Brewer (2002). Comparison of agricultural and power plant by product gypsum for south Texas peanut production. Texas J. Agric. Nat. Res. 15: 44 - 50.

Hallock, L. D. and A. H. Allison (1980a). Effect of three Ca sources applied on peanut I: Productivity and seed quality peanut Sci. 7: 19-25.

Hussein, M. E., A. L. Abdel-Latif, O. F. ElSedfy and Z. M. Abdel-Rahman (2011). Impact of some organic sources on nutrients availability, growth and potato yield grown in sandy soil. Egypt. J. Soil Sci.

Ismail, A. (B. 2002). Studies on nutrient uptake by plant as affected by soil conditioners and water stress under greenhouse condition. Ph.D. Thesis Fac. Agric. Moshtohor, Zagazig univ. Egypt. 
Jackson, M. L. (1973). Soil chemical analysis. Prentice - Hall of India, private and LTD. New Delhi, $2^{\text {nd }}$ Indian Rep.

Keisling, T. C. and M. E. Walker (1982). Calcium absorption efficiency of peanut fruit of various cultivars. J. of Plant Nutr. 5: 90-95.

Khater, E. A., S. B. Ibrahim and A. A. Awadalla (2004). Utilization of some farm organic wastes for improving soil productivity of the newly reclaimed areas at El-Fayoum Governorate Egypt. Egypt J. Soil Sci. 44(3): 333342.

Klute, A. (1986). Methods of analysis. Part I, soil physical properties. ASA and SSSA, Madison. WI.

Mahrous, N. M., S. A. Sayed, H. A. Hatem and M. E. El-Balak (2015). Integrated use of organic, inorganic and bio fertilizers on yield and quality of two peanut cultivars grown in a sandy saline soil. American - Euro Asian. J. Agric. And Environ. Sci. 5(6):1067 1074.

Mobark, S., N. Labidi, H. Mohamoud, N. Jedidi and C. Abdelly (2000). Contrasting effect of municipal compost on alfalfa growth in clay and sandy soils, N, P, K contents and heavy metal toxicity. Blore Source Thechnol. 99: 6745-6750.

Page, A. L., R. H. Miller and D. R. Keeny (1982). "Methods of soil analysis part II: chemical and microbiological properties. 2nd Ed. Am.

Radwan, S. M. and N. M. Awad (2002). Effect of soil amendments with various organic wastes with multi biofertilizer on yield of peanut plants in sandy soil. J. of Agric. Sci. of Mansoura 27(5): 3129 - 3138 .

Rao, S. S. and Shaktawt (2005). Effect of organic manure, phosphorous and gypsum on nutrient uptake in groundnut. Agropedology, 15(2): 100106.

Safarzadeh, M.N., A. Hossinzadeh, S. M. Mazhari and A. Ramazani (2002). Effect of gypsum on growth and yield of peanut. 17 WCSS: 14-21, August 2002, Thailand.

Safarzadeh, V. M. N. (2004). Effect of gypsum application time and rate on growth and yield of peanut on Guiluan Provence. Iran World Appl. Sci. J. 16(4): 540-550.

Salama, D. C. and A. D. Rovira (1994). Floer production and yield of groundnut under various concentration of organic yield manure and water amount. Annals Agric. Sci. Moshtohor, Egypt. 32(1): 1-19.

Sendecor, G. and W. G. Cochron (1980). Statistical methods, $7^{\text {th }}$ Ed; I Owa Stute Univ. Press, low, U.S.A.

Singh, H. P. (1980). Soil improvement in relation to dry land agriculture storage in sandy desert soil. Indian Nat. Sci. Acad., B44 (4): 187 - 190. (c.f. Soil and Fert., (43): Abst. No. 3722).

Staffelle, P. J. and D. A. Graez (2000). Utilization of sugarcane compost as soil amendment in tomato production system. Compost soil Sci. Util. 8: 210214.

Summer, M. E., C. S. Kvner, H. Smal and A. S. Csines (1988). On calcium nitration of peanut (Arahis hypogaea L.). Conceptual model. J. Fertilizer Issues. 5: 97 - 102.

Walker, M. E. and T. C. Keisling (1978). Response of five peanut cultivars to gypsum fertilization on soils varying in calcium content. Peanut science 5: 57-60. Dol.

Yang, R. (2015). Calcium availability to Runner - Type peanut (Arahis hypogaea L.) in south eastern United State. MSc. Auburn Uni. U.S.A. 
تأثير إضافة السماد العضوى والجبس والرش بالكالسيوم على محصول وجودة نبات الفول

$$
\text { السودانى النامى فى أرض رملية }
$$

فاتن عبد العزيز عباس ، ياسر محمد الإدفاوى ، رشاد عبد المنعم درار

مركز البحوث الزراعية - معهة بحوث الأراضى والمياه والبيئة - الجيزة.

الملخص العربى (أحسى

أجريت تجريتان حقليتان فى محطة اللإسماعيلية التلبعة لمركز البحوُ الزراعية - مصر . لموسمين متعاقبين صيف

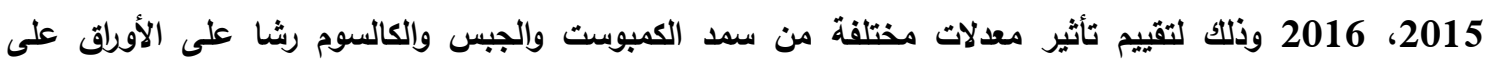

المحصول ومكوناته وجودة نبات الفول السودانى النامى فى أرض رملية واشتملت التجرية على 12 معاملة بثلاثة مكررات

بنظام القطاعات تامة العشوائية كلآتى:

.Control (without application) -1

.Compost application at rate of $12.5 \mathrm{Mg} \mathrm{ha}-1$ (C1) -2

.Compost application at rate of $25 \mathrm{Mg}$ ha-1 (C2) -3

.Gypsum application at rate of $0.6 \mathrm{Mg}$ ha-1 (G1) -4

.Gypsum application at rate of $1.2 \mathrm{Mg}$ ha-1 (G1) -5

$\mathrm{Ca}-$ chelate at rate of $300 \mathrm{mg} \mathrm{L}-1$ as foliar application (Ca foliar) -6

C1+ G1 -7

$C 1+G 2-8$

C2 + G1 -9

C2 + G2-10

C1 + Ca foliar -11

C2 + Ca foliar -12

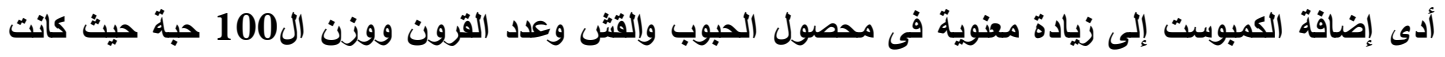

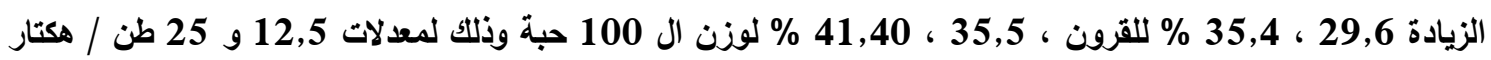
على التوالى. كما أوضحت النتائج بأن إضافة الجبس بمعدلاته أدى الى زيادة معنوية فى المحصول ومكوناته اله ومحصول

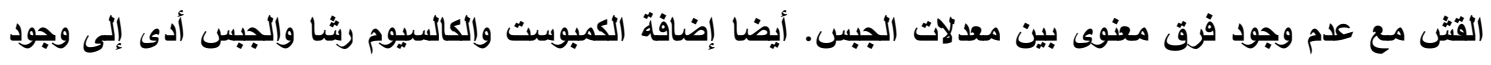
زيادة معنوية فى محتوى العناصر الكبرى والصغرى ، كما أن محتوى الحبوب من الزيت ونسبة البروتين زاد معنويا بإضافة إنيا السماد العضوى والجبس. 
Faten A. Al-Kamar, et al.,

أسماء السادة المحكمين

$$
\begin{aligned}
& \text { أ.د / محمد عبدالنغسى حسن معهل بحوث الأراضى والمياه والبيئة - الجيزة }
\end{aligned}
$$

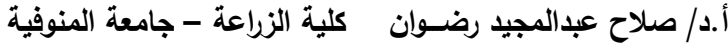

